\title{
Postoperative Diffuse Peritonitis Causing Adhesive Bowel Obstruction Possibly Due to Sars-Cov-19 Infection: Report of a Case
}

\author{
Sars-Cov-19 Enfeksiyonu Sonrası Adeziv Bağırsak Tıkanıklığına \\ Neden Olan Cerrahi Sonrası Yaygın Peritonit: Olgu Sunumu
}

\author{
Tutku SOYER ${ }^{1}$, Ozlem BOYBEYI TURER ${ }^{1}$, Yasemin OZSUREKCl'², Diclehan ORHAN³, \\ Mehmet CEYHAN ${ }^{3}$, Feridun Cahit TANYEL ${ }^{1}$
}

${ }^{1}$ Hacettepe University, Faculty of Medicine, Departments of Pediatric Surgery, Ankara, Turkey

${ }^{2}$ Hacettepe University, Faculty of Medicine, Departments of Pediatric Infectious Disease, Ankara, Turkey

${ }^{3}$ Hacettepe University, Faculty of Medicine, Departments of Pediatric Pathology, Ankara, Turkey

\begin{abstract}
Aim is to discuss diagnostic and therapeutic difficulties in COVID-19 related postoperative outcomes. A 5-year-old boy operated for jejunal atresia in neonatal period admitted with recurrent bilious vomiting. The upper Gl series revealed dilated jejunum and absence of mechanical obstruction. The dilated jejunal segment was excised and anastomosis was performed. Later, he developed peritonitis without signs of anastomotic leaks. The second surgical exploration revealed diffuse peritonitis causing thickened and fibrous bowel loops causing hardly lysable adhesions. Then, his grandmother was learned to be COVID-PCR positive. Therefore, patients with atypical postoperative course should be investigated for possible COVID-19 during pandemics.
\end{abstract}

Key Words: Adhesive obstruction, Children, Peritonitis, Postoperative, SARS-CoV-2

\section{Öz}

Amacımız cerrahi sonrası sonuçlarda COViD-19 ilişkili tanı ve tedavi güçlüklerini tartışmaktır. Yenidoğan döneminde jejunal atrezi nedeniyle ameliyat olan 5 yașında erkek hasta tekrarlayan safralı kusma nedeniyle bașvurdu. Üst Gis tetkikinde mekanik tıkanıklik olmadan jejunal segment dilatasyonu izlendi. Dilate jejunuma rezeksiyon ve anastomoz yapıldı. Sonrasında, anastamoz kaçağı olmayan hastada peritonit bulguları geliști. İkinci cerrahi eksplorasyonda zor ayrilabilen adeziv bantlara neden olan kalınlaşmış fibröz bantlar ve yaygın peritonit izlendi. Hastanın tekrarlanan öyküsünden büyükannesinde cerrahi öncesinde COViD-PCR pozitifliği olduğu öğrenildi. Dolayısıyla, pandemi süreci boyunca atipik post-operatif seyir yaşayan hastalarda COVID-19 araştırması yapılmalıdır.

Anahtar Kelimeler: Adeziv tıkanıklık, Çocuk, Peritonit, Postoperatif, SARS-CoV-2

\section{INTRODUCTION}

Although respiratory system appears to be main target of SARSCoV-2 infection, which is later called COVID-19, gastrointestinal involvement can be seen in 20\% of children (1). Diarrhea and vomiting are the most common symptoms in pediatric age group and are seen in 8-9\% of all infected patients (2). The presenting symptoms and clinical course of COVID-19 is atypical in children and high index of suspicion is needed in asymptomatic patients. Although there is no evidence of viral replication in gut epithelial cells, COVID-19 may cause appendicitis and intussusception in children $(3,4)$. Lei et al. (5) reported that asymptomatic infection on admission for elective surgical procedures was associated with the evidence of increased inflammatory response and more adverse outcomes in adults. To the best of our knowledge, there is no information exists regarding the postoperative outcomes in children undergoing elective surgery with asymptomatic COVID-19. Therefore, we
(1)

0000-0003-1505-6042: SOYER T 0000-0002-0465-7793: BOYBEYI TURER O 0000-0001-8662-6909: OZSUREKCI Y 0000-0003-3637-5392: ORHAN D D000-0002-2318-3394: CEYHAN M 0000-0002-8301-3012: TANYEL FC
Conflict of Interest /Çıkar Çatışması: On behalf of all authors, the corresponding author states that there is no conflict of interest. Financial Disclosure / Finansal Destek: The authors declared that this case has received no financial support. Confirmation / Onay: The written consent was received from the patient who was presented in this study.

How to cite / Atıf Yazım Sekli : Soyer T, Boybeyi Turer O, Ozsurekçi Y, Orhan D, Ceyhan M, Tanyel FC. Postoperative Diffuse Peritonitis Causing Adhesive Bowel Obstruction Possibly Due to Sars-Cov-19 Infection: Report of a Case. Turkish J Pediatr Dis 2022;16:165-167. 
aimed to present the first case of diffuse peritonitis causing adhesive bowel obstruction due to COVID-19 in children.

\section{CASE PRESENTATION}

The patient's anonymity is protected and informed consent was obtained from the parents. A 5-year-old boy operated for jejunal atresia in neonatal period admitted to our department with recurrent episodes of bilious vomiting and abdominal pain. The upper Gl series revealed dilated jejunal segments with low transit time, but without mechanical obstruction. Elective surgical exploration of jejunal anastomosis was planned. On admission, body temperature was $36.5^{\circ} \mathrm{C}$, blood pressure was $90 / 60 \mathrm{mmHg}$, respiratory rate was $14 /$ minutes, and heart rate was $90 / \mathrm{min}$. The laboratory investigations including total blood count and liver and renal function tests were within normal limits. There was no sign of inflammation and C-reactive protein (CRP) level was $0.11 \mathrm{mg} / \mathrm{dl}$ (normal range; 0-0.5 mg/ dl) at admission. Polymerase chain reaction (PCR) testing for COVID-19 was also negative. Surgical exploration with right upper transvers incision revealed extremely dilated jejunum proximal to anastomotic site. The dilated jejunal segment was excised and end-to-end duodenojejunal anastomosis was performed. The histopathology of the excised bowel showed no microorganisms in bowel epithelium and revealed increased fibrosis and lymphocyte infiltration on thickened bowel wall (Figure 1). After an uneventful four postoperative day, he developed peritonitis and adhesive bowel obstruction without signs of anastomotic leaks and/or bowel perforation. Abdominal x-ray revealed large air fluid levels (Figure 2). A nasogastric tube was inserted and oral feedings were stopped. The patient developed diarrhea while nasogastric tube drained more than $1000 \mathrm{ml}$ daily. He developed decreased levels of lymphocytes $\left(0.95 \times 10^{3} \mu \mathrm{l},\right)$ and signs of peritonitis. The CRP level (0.56 mg/dL, normal range:0-0.8 mg/dL) was normal. The control COVID-19 PCR test obtained from nasopharyngeal swab was still negative. The signs of peritonitis were progressed and general condition of the patient become unstable. The

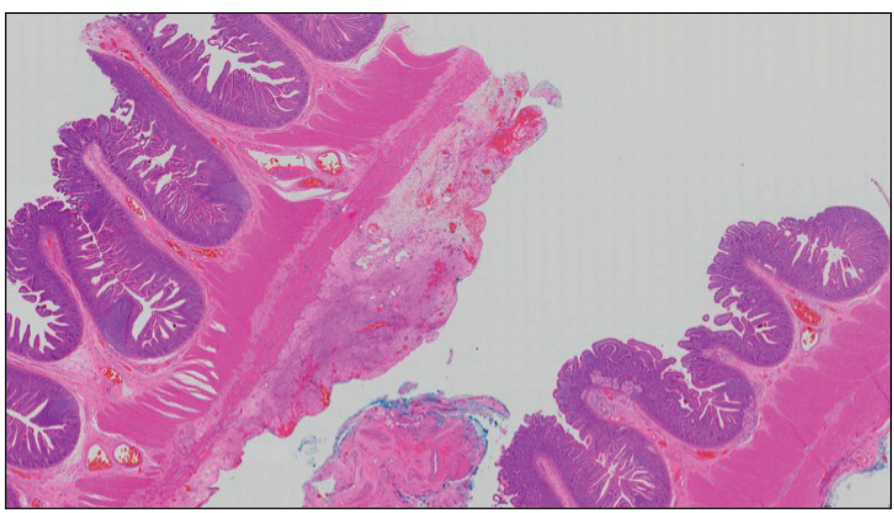

Figure 1: Histopathology of excised bowel reveals increased fibrosis and lymphocyte infiltration on thickened bowel wall (Hematoxylin \& eosin, $x$ 40). second surgical exploration revealed diffuse peritonitis causing thickened and fibrous bowel loops. This thickened and inflamed intestinal serosa caused hardly lysable adhesions between bowel loops. Broad spectrum of antibiotics covering both aerobic and anaerobic bacteria was continued for three weeks. Three weeks after the second exploration, patient tolerate oral feedings. When medical history of the patient detailed, the parents report that the grandmother of the patient was positive for COVID-19 before the surgical treatment. Then, we evaluated Euroimmun Anti-SARS-CoV-2 ELISA Ig-G in serum and found positive $(>1.5$, normal range; $<0.5)$. The patient was diagnosed as postoperative diffuse peritonitis causing adhesive bowel obstruction due to COVID-19. No other treatment regimen was ordered. He was discharged uneventfully with full oral-feedings.

\section{DISCUSSION}

At the beginning of COVID-19 pandemics, it has been observed that the disease has milder symptoms and low mortality in younger age groups (6). As the pandemics advances, large number of children becomes symptomatic with toxic shock syndrome including severe cutaneous, gastrointestinal and cardiac problems, which is called pediatric multi system inflammatory syndrome (MIS-C). Although diarrhea and vomiting are common gastrointestinal symptoms, gastrointestinal manifestations of COVID-19 may mimic and/ or cause acute abdominal findings such as appendicitis, intussusception, gastrointestinal bleeding, and pneumatosis intestinalis in children $(3,4)$. Herein, we report the first case of postoperative diffuse peritonitis causing adhesive obstruction due to COVID-19 in children. Moreover, the diagnosis of MIS-C was excluded because of the absence of persistent fever, rash, conjunctivitis, and any other organ involvement but gut with normal acute phase response. Therefore, this rare clinical presentation let us consider the possible role of isolated direct and/or immune-mediated gastrointestinal system involvement of SARS-CoV-2.

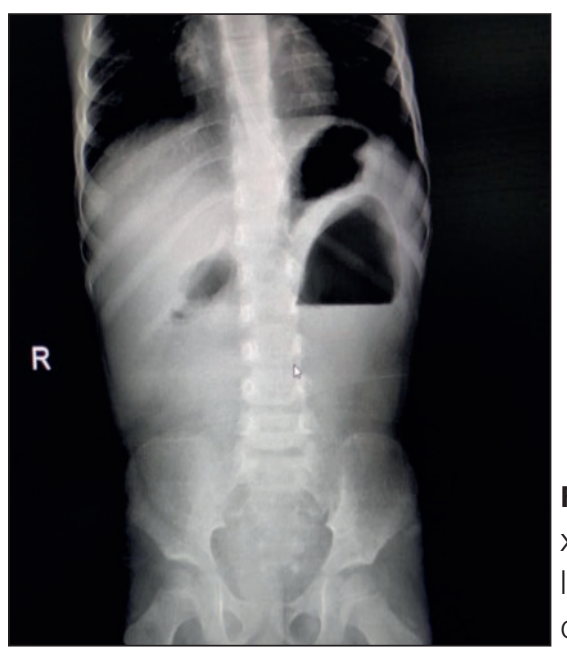

Figure 2: Abdominal $x$-ray showing air-fluid levels at the time of diffuse peritonitis. 
The PCR test for COVID-19 infection obtained from nasopharyngeal swabs revealed $21 \%$ positivity in children with gastrointestinal symptoms (8). Since gastrointestinal system is considered as a route for viral entry, nasopharyngeal PCR tests can be negative in the absence of respiratory symptoms. In our case, nasal swabs were negative in both operations. The patient diagnosed COVID-19 with positive antibody test in postoperative period. Wang et al. (8) reported that $85 \%$ of patient's had positive fecal nucleic acid testing and $71.2 \%$ of them continue to be positive after the respiratory PCR test turned to negative. Therefore, it is difficult to diagnose gastrointestinal involvement in children with COVID-19 especially in patients with previous gastrointestinal surgery. In our patient, the clinical findings of COVID-19 mimic postoperative adhesions by causing diffuse peritonitis. The physical examination of the patient revealed abdominal tenderness and signs of peritonitis. Despite adhesive obstruction findings in abdominal X-ray and high volume of nasogastric drainage, patient developed watery diarrhea during clinical follow-up. This atypical presentation suggested that a systemic inflammatory problem might complicate the postoperative period. Although, we suggest that COVID-19 may cause the clinical scenario, negative PCR tests did not confirm our diagnosis. However, we confirmed the diagnosis 30 days after the surgical treatment with positive Ig $G$ levels. This case suggests that the analyses of fecal nucleic acid test in cases with gastrointestinal involvement are of great importance to understand the possible nature of extra pulmonary organ involvements.

In patients with gastrointestinal surgery, early postoperative peritonitis is likely secondary to previous surgery and anastomotic leaks and bowel perforation are responsible for the clinical findings. Adhesive obstructions after abdominal surgery seldom need re-exploration in early postoperative period and resolves with conservative management with bowel rests and nasogastric decompression. Despite diffuse peritonitis, antibiotic treatment with conservative management is adequate in most cases and surgical intervention is needed in the presence of complications such as perforation. In our patient, it was difficult to differentiate the cause of peritonitis. Since, the patient had resection and anastomosis, a secondary peritonitis due to leak or perforation was suggested. However, surgical exploration revealed primary peritonitis due to COVID-19.

In adult studies, it has been reported that asymptomatic infection on admission for elective surgical procedures was associated with increased inflammatory response and more adverse outcomes (5). There is no information regarding the effect of COVID-19 on response to surgery and its impact on postoperative outcomes. Therefore, we suggest that diffuse postoperative peritonitis due to COVID-19 should be kept in mind in patients with atypical postoperative course in children.

In conclusion, COVID-19 may cause diffuse postoperative peritonitis causing adhesive obstruction and misdiagnosed as acute abdomen in children. Patients with atypical postoperative course and signs of diffuse peritonitis should be investigated for possible COVID-19 during pandemics. The PCR tests obtained from either nasal or fecal swabs cannot be positive in all cases but may avoid unnecessary surgical exploration in positive cases.

\section{REFERENCES}

1. Chiappini E, Licari A, Motisi MA, Manti S, Marseglia GL, Galli L, et al. Gastrointestinal involvement in children with SARS-COV-2 infection: An overview for the pediatrician. Pediatr Allergy Immunol 2020; 31: 92-5.

2. Matthai J, Shanmugam N, Sobhan P. Coronavirus disease (COVID-19) and the gastrointestinal system in children. Indian Pediatr 2020; 57: 533-5.

3. Malhotra A, Sturgill M, Whitley-Williams P, Li YH, Esochaghi C, Rajasekhar H, et al. Pediatric COVID-19 and Appendicitis: A Gut Reaction to SARS-CoV-2? Pediatr Infect Dis J 2020; 40: 49-55.

4. Makrinioti $H$, MacDonald A, Lu X, Wallace S, Jobson M, Zhang F, et al. Intussusception in Children with Severe Acute Respiratory Syndrome Coronavirus Infection. J Pediatric Infect Dis Soc 2020; 17: 504-6.

5. Lei S, Jiang F, Su W, Chen C, Chen J, Mei W, et al. Clinical characteristics and outcomes of patients undergoing surgeries during the incubation period of COVID-19 infection. E-Clinical Medicine 2020; 5: 100331.

6. Zou H, Lu J, Liu J, Wong JH, Cheng S, Li Q, et al. Characteristics of pediatric multi-system inflammatory syndrome (PMIS) associated with COVID-19: a meta-analysis and insights into pathogenesis. Int $\mathrm{J}$ Infect Dis 2020; 14: 319-26.

7. Foster CE, Marquez L, Davis AL, Tocco E, Koy TH, Dunn J, et al. A Surge in Pediatric Coronavirus Disease 2019 Cases: The Experience of Texas Children's Hospital from March to June 2020. J Pediatric Infect Dis Soc 2021; 10: 593-8.

8. Wang JG, Cui HR, Tang HB, Deng XL. Gastrointestinal symptoms and fecal nucleic acid testing of children with 2019 coronavirus disease: a systematic review and meta-analysis. Sci Rep 2020; 20:17846. 